\title{
Condensation of 2-Naphthol and Naphthalenediols with $o$-Dichlorobenzene in the Presence of Aluminum Halides
}

\author{
Konstantin Yuryevich Koltunov, ${ }^{a, b, c}$ Aleksey Nikolaevich Chernov, ${ }^{a, b}$ \\ Gubbi Krishnamurthy Surya Prakash, ${ }^{*, c}$ and George Andrew Olah ${ }^{c}$ \\ ${ }^{a}$ Boreskov Institute of Catalysis; Pr. Akademika Lavrentieva, 5, Novosibirsk 630090, Russia: ${ }^{b}$ Novosibirsk State Uni- \\ versity; Pirogova, 2, Novosibirsk 630090, Russia: and ${ }^{c}$ Loker Hydrocarbon Research Institute and Department of \\ Chemistry, University of Southern California; University Park, Los Angeles, California 90089-1661, U.S.A. \\ Received December 14, 2011; accepted March 28, 2012; published online April 11, 2012
}

It is known that 1-naphthol, as a result of superelectrophilic (dicationic) activation in superacid media, is able to react with such deactivated aromatic compound as $o$-dichlorobenzene to give 4-(3,4-dichlorophenyl)1-tetralone (2), which is a highly valuable intermediate in the synthesis of the antidepressant, sertraline (1) and other useful derivatives. However, the analogous reactivity of 2-naphthol and a variety of naphthalenediols towards $o$-dichlorobenzene has not been investigated thus far, although the corresponding tetralones, bearing dichlorophenyl moiety, could be of great pharmacochemical interest. In present work, we disclose that 1,5-, 1,6-, and 1,7- naphthalenediols $(6 a-c)$ react smoothly with $o$-dichlorobenzene in the presence of an excess of aluminum chloride or aluminum bromide to give the pairs of isomeric 4-(3,4-dichlorophenyl)- and 4-(2,3-dichlorophenyl)- 5-, 6-, and 7-hydroxy-1-tetralones (10a-c and 11a-c) in high overall yields. 2-Naphthol and 2,7-naphthalenediol (6d) exhibited comparatively lower reactivity, which however was sufficient to obtain the corresponding dichlorophenyl-2-tetralones in moderate yields. The mechanism of these reactions involving superelectrophilic dicationic or even tricationic intermediates, is discussed.

Key words superacid; superelectrophilic activation; 2-naphthol; naphthalenediol; tetralone

Tetralones are useful molecules as starting material for the synthesis of biologically active compounds and pharmaceutical substances. ${ }^{1-8)}$ For example, one of the major commercial pharmaceutical agents, sertraline $((+)-c i s-(1 S, 4 S)-1-$ methylamino-4-(3,4-dichlorophenyl)tetralin, 1), an antidepressant known under the trade name Zoloft, is a competitive inhibitor of synaptosomal serotonin uptake.9,10) The current commercial process for the production of sertraline involves the synthesis of $( \pm)-\mathbf{1}$ followed by resolution. ${ }^{1,3,11-14)}$

A key intermediate in the synthesis of $\mathbf{1}$ is 4-(3,4-dichlorophenyl)-1-tetralone (2), which has been prepared by a few synthetic routes. ${ }^{15-17)}$ The most efficient route to tetralone 2 is based on one-stage condensation reaction of 1 -naphthol with $o$-dichlorobenzene under the influence of aluminum halides. ${ }^{3,16,17)}$

Originally, a similar method for the synthesis of 4-aryl1-tetralones had been demonstrated for reactions of 1-naphthol with benzene, chlorobenzene, fluorobenzene and toluene under the influence of aluminum halides or in the $\mathrm{HF}-\mathrm{SbF}_{5}$ superacid medium ${ }^{18-22)}$ (Chart 1). Analogously, 2-naphthol reacts with benzene in the presence of aluminum halides to give 4-phenyl-2-tetralone ${ }^{19,23)}$ (Chart 1). Furthermore, selective ionic reduction of naphthols by alkanes leads to tetralones under similar reaction conditions ${ }^{24,25)}$ (Chart 1).

The mechanism of these reactions was recognized to involve superelectrophilic ${ }^{26)}$ dications (structures 3 and $\mathbf{4}$, Chart 1) as the key intermediates formed by $C, C$-diprotonation and a number of analogous dications have indeed been generated as long-lived species by dissolving naphthols and/or their derivatives in liquid superacids. ${ }^{27,28)}$ Moreover, a set of isomeric naphthalenediols was reacted similarly with benzene and cyclohexane in the presence of $\mathrm{AlBr}_{3}$ and $\mathrm{AlCl}_{3}$ to afford the corresponding hydroxytetralones ${ }^{29-31)}$ (Chart 2).

In addition, it has been found that, in contrast to 1-naphthol and naphthalenediols, 5-amino-1-naphthol is activated by
$N, C$-diprotonation in superacids and reacted with benzene and cyclohexane under the influence of aluminum halides through dications 5 to give 5-amino-3-phenyl-1-tetralone and 5-amino1-tetralone, respectively ${ }^{32)}$ (Chart 3)

Based on this background, in continuation of our interest in superelectrophilic activation of naphthols and their derivatives, a study on the reactivity of 2-naphthol and isomeric 1,5-, 1,6-, 1,7-, and 2,7-naphthalenediols $(\mathbf{6 a}-\mathbf{d})^{33)}$ towards $o$-dichlorobenzene is reported with the aim of synthesizing the corresponding dichlorophenyl-1- and 2-tetralones, which are considered as promising intermediates for medicinal chemistry. ${ }^{834}$ The main aim of the work was also to determine the regioselectivity of these reactions.

\section{Results and Discussion}

Reactions of 2-Naphthol Until now, attempts to involve 2-naphthol in reaction with $o$-dichlorobenzene were not successful. ${ }^{23)}$ Thus, 2-naphthol did not give any product at conditions, essential for the reaction of 1-naphthol, which reacted with $o$-dichlorobenzene in the presence of an excess of $\mathrm{AlCl}_{3}$ (or $\mathrm{AlBr}_{3}$ ) at elevated temperature, normally at $100-120^{\circ} \mathrm{C}$ $\left(65^{\circ} \mathrm{C}\right)$, to give tetralone 2 in $65-80 \%$ yield over $1-2 \mathrm{~h} .^{3,16,17)}$ Therefore, at the time it was concluded that dicationic intermediate $\mathbf{4}$ is not electrophilic enough to react with such

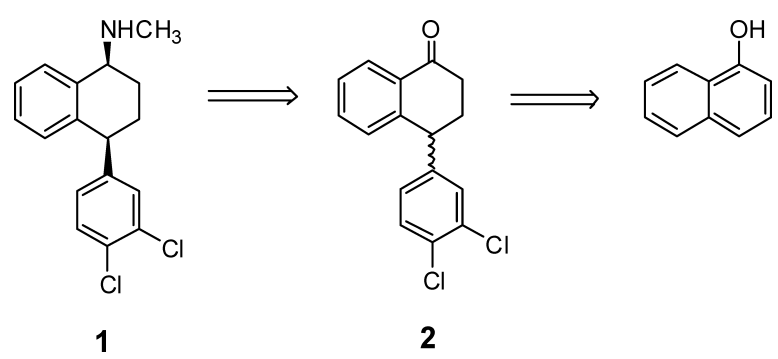




$$
\text { Superacid }
$$

Chart 1. Reactions of Naphthols with Arenes (ArH) and Alkanes (AlkH).

deactivated aromatic compound as $o$-dichlorobenzene. Indeed, according to density functional theory (DFT) calculations, dication $\mathbf{4}$ is less electrophilic compared to the diprotonated form of 1-naphthol ${ }^{35)}$ (structure 3).

Nevertheless, 2-naphthol was observed to react with $o$ dichlorobenzene to give isomeric 4-(3,4-dichlorophenyl)- and 4-(2,3-dichlorophenyl)-2-tetralones 7 and 8 in ca. 9:1 ratio, respectively, in a moderate overall yield. A condition, favorable to ensure the successful result, appeared to be a long term reaction performed at room temperature (Table 1).

The plausible mechanism of the reaction includes generation of dications 4 , similar to that described in Chart 1. Dications $4(\mathrm{X}=\mathrm{H})$ have been previously detected by ${ }^{1} \mathrm{H}$ - and ${ }^{13} \mathrm{C}-\mathrm{NMR}$ spectroscopy as long-lived species in $\mathrm{HF}_{-} \mathrm{SbF}_{5}$ $\mathrm{SO}_{2} \mathrm{ClF}$ superacid system at $-40{ }^{\circ} \mathrm{C} .{ }^{28)}$ However, in the presence of aluminum halides, participation of dicationic species 4 $\left(\mathrm{X}=\mathrm{Al}_{n} \mathrm{Hal}_{3 n}^{-}, \mathrm{Hal}=\mathrm{Cl}, \mathrm{Br}\right.$ ) seems more probable, as 2-naphthol is converted quantitatively into complexes $\mathbf{9}$ upon action of $\mathrm{AlCl}_{3}$ and $\mathrm{AlBr}_{3}{ }^{36)}$ The subsequent $C$-protonation of 9 results in formation of $4\left(\mathrm{X}=\mathrm{Al}_{n} \mathrm{Hal}_{3 n}^{-}\right)$in equilibrium with 9. A catalytic amount of protic superacid $\left(\mathrm{HHal}-\mathrm{Al}_{n} \mathrm{Hal}_{3 n}\right.$ or $\mathrm{H}_{2} \mathrm{O}-\mathrm{Al}_{n}$ $\mathrm{Hal}_{3 n}$ ), which is required for $C$-protonation of intermediate species 9, is normally present in such reaction media due to presence of traces of water in the starting materials. The acid strength of $\mathrm{HHal}-\mathrm{Al}_{n} \mathrm{Hal}_{3 n}(\mathrm{Hal}=\mathrm{Br}, \mathrm{Cl})$ is estimated to be -15 to -18 in the $H o$ scale. ${ }^{37-39)}$ So, additional saturation of the reaction mixture with gaseous HHal, which usually accelerates similar reactions, ${ }^{40)}$ is not generally needed.

Taking into account a quantitative recovery of unreacted 2-naphthol, it is very likely that the moderate yield of tetralones 7 and $\mathbf{8}$ (no more than $36 \%$, Table 1) is close to the equilibrium concentration of the product. The sensitivity of the reaction to the reverse process is in agreement with the known reactivity of 2-naphthol towards benzene. Thus, in spite of a $90 \%$ yield of 4-phenyl-2-tetralone in reaction of 2-naphthol with benzene in the presence of a 2.5-fold molar excess of $\mathrm{AlCl}_{3}\left(20^{\circ} \mathrm{C}, 16 \mathrm{~h}\right),{ }^{19)}$ the equilibrium of a similar reaction is shifted completely to 2-naphthol, when $\mathrm{HF}_{-} \mathrm{SbF}_{5}$ superacid at $-20^{\circ} \mathrm{C}$ or HUSY-zeolites at $130^{\circ} \mathrm{C}$ used. ${ }^{23,41)}$ The observed poor reactivity of 2-quinolinol (heterocyclic analog of 2-naphthol) towards benzene is also relevant to this case. ${ }^{42)}$

Reactions of Naphthalenediols $\mathbf{6 a}-\mathbf{c}$ For isomeric naphthalenediols, the possibility of superelectrophilic activation has been demonstrated earlier only for their reactions with cyclohexane and benzene ${ }^{29-31)}$ (Chart 2). Reactions of

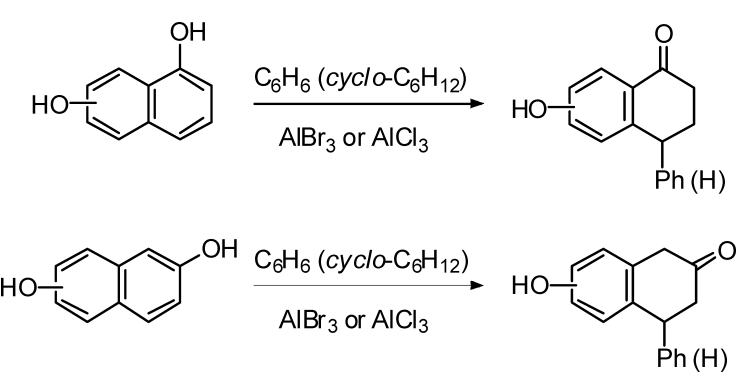

Chart 2. Reactions of Naphthalenediols with Benzene and Cyclohexane

\begin{tabular}{|c|c|c|c|}
\hline \multicolumn{3}{|c|}{ Reaction conditions } & \multirow{2}{*}{$\begin{array}{c}7 \text { and } 8 \text { overall } \\
\text { yield }^{a)}(\%)\end{array}$} \\
\hline Acid (eq) & Time (d) & $T\left({ }^{\circ} \mathrm{C}\right)$ & \\
\hline $\mathrm{AlCl}_{3}(3.0)$ & 7 & 25 & 11 \\
\hline $\mathrm{AlCl}_{3}(3.0)$ & 14 & 25 & 19 \\
\hline $\mathrm{AlCl}_{3}(5.0)$ & 14 & 25 & 35 \\
\hline $\mathrm{AlCl}_{3}(5.0)$ & 14 & 60 & 24 \\
\hline $\mathrm{AlCl}_{3}(5.0)$ & 1 & 110 & 1 \\
\hline $\mathrm{HCl}-\mathrm{AlCl}_{3}(3.0)$ & 7 & 25 & 29 \\
\hline $\mathrm{HCl}-\mathrm{AlCl}_{3}(3.0)$ & 14 & 25 & 36 \\
\hline $\mathrm{AlBr}_{3}(3.5)$ & 7 & 25 & 24 \\
\hline $\mathrm{AlBr}_{3}(3.5)$ & 1 & 60 & 1 \\
\hline
\end{tabular}

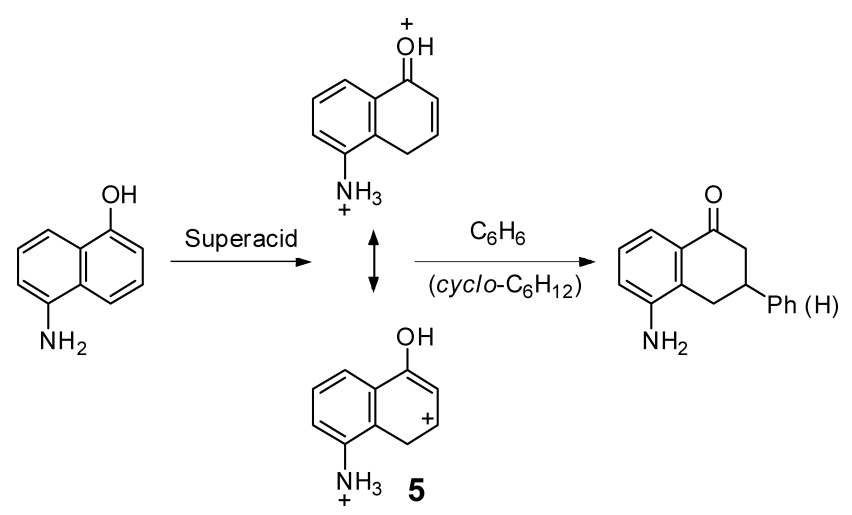

Chart 3. Reactions of 5-Amino-1-naphthol with Benzene and Cyclohexane

Table 1. Electrophilic Reactions of 2-Naphthol

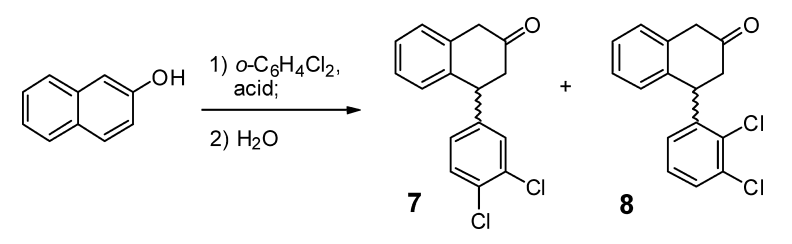

a) Based on ${ }^{1} \mathrm{H}-\mathrm{NMR}$ spectroscopic data. The balance is mainly unreacted 2-naphthol. The ratio of $\mathbf{7 / 8}$ is about $9: 1$ in each case.

diols $\mathbf{6 a}-\mathbf{c}$ with the electrondeficient $o$-dichlorobenzene gave products similar to 1-naphthol. Reactions took place under the influence of a 3-fold molar excess of $\mathrm{AlCl}_{3}$ at $110^{\circ} \mathrm{C}$ or $\mathrm{AlBr}_{3}$ at $25^{\circ} \mathrm{C}$ to give pairs of 5-, 6-, and 7-hydroxysubstituted 4-(3,4-dichlorophenyl)-1-tetralones $(\mathbf{1 0 a}-\mathbf{c})$ and 4-(2,3-dichlorophenyl)-1-tetralones $(\mathbf{1 1 a}-\mathbf{c})$, respectively, in ca. $95 \%$ overall yields (Table 2 ).

The ratio of isomers $\mathbf{1 0 a}-\mathbf{c}$ and $\mathbf{1 1 a}-\mathbf{c}$ in the obtained mixtures is about $4: 1$, in each case. The same ratio of product 2 and isomeric 4-(2,3-dichlorophenyl)-1-tetralone was found, 
previously, for the reaction of 1-naphthol with $o$-dichlorobenzene. ${ }^{17)}$ This is to be expected based on these reactions having a common mechanism. Dicationic electrophiles $12(\mathrm{Y}=\mathrm{OH})$, which are the key intermediates of the reactions studied, may also be additionally protonated (or coordinated with aluminum halide) to give tricationic $12\left(\mathrm{Y}=\mathrm{OHX}^{+}\right)$in the limiting cases. Differences in the activation of naphthalenediols $\mathbf{6 a}-\mathbf{c}$ compared to 5-amino-1-naphthol (Chart 3) can be explained by the weaker basicity of hydroxy group in relation to the aminogroup. As a consequence, higher equilibrium concentration of $C, C$-diprotonated forms can be found in the first case. On the other hand, $O, C$-diprotonated dications $13(\mathrm{X}=\mathrm{H})$ and similar complexes $13\left(\mathrm{X}=\mathrm{Al}_{n} \mathrm{Hal}_{3 n}^{-}\right)$, which are comparatively more easily formed, ${ }^{43,44)}$ than $C, C$-diprotonated forms $\mathbf{1 2}$, do not react with $o$-dichlorobenzene, probably, because of the diminished electrophilicity. Therefore, intermediates $\mathbf{1 2}$ are stronger electrophiles and could react predominantly despite their relatively low equilibrium concentrations. Calculational estimations of electrophilicity of a number of dications showed, for example, that $C, C$-diprotonated naphthols are more electrophilic than $N, C$-diprotonated 5-amino-1-naphthol (structure 5) and isomeric hydroxyquinolines. ${ }^{32,35)}$

The main products $\mathbf{1 0}$ can be isolated from the reaction mixture by simple recrystallization. Moreover, undesired tetralones $\mathbf{1 1}$ can also be transformed into the useful isomers 10. For example, the mixture of isomers $\mathbf{1 0 b}$ and $\mathbf{1 1 b}$ with the ratio 45:55 (obtained from the mother liquor after recrystallization of the initial mixture) gave the equilibrium ratio $78: 22$ after $15 \mathrm{~h}$ reaction in $o$-dichlorobenzene with $\mathrm{AlCl}_{3}$ at $120^{\circ} \mathrm{C}$. Such isomerisation of aryltetralones have earlier been

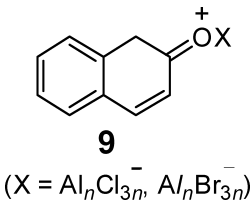

reported. $^{20)}$

Based on the structure-activity relationship of $\mathbf{1}$ and its derivatives, it is well known that the presence of 3,4-dichlorophenyl group is actually necessary to induce the biological activities and the attempts to improve the activities by variation of 4-aryl-group were unsuccessful. ${ }^{45)}$ Nevertheless, the properties of 1 should likely be improved by structural changes in the tetraline aromatic ring. Literature precedence exists for this contention as 4-(4-chlorophenyl)-1-methylaminotetralin (the close analog of 1) has been reported to exhibit close or even enhanced therapeutic properties due to introduction of 7-methoxy group. ${ }^{45}$ This provides an incentive that similar functionalized derivatives of $\mathbf{1}$ can be pharmaceutically important. From this point of view, the presently obtained products $\mathbf{1 0 a}-\mathbf{c}$ or their close derivatives, as alkyl or aryl ethers and others may serve as useful synthons for the synthesis of analogs of $\mathbf{1}$.

Reactions of Naphthalenediol 6d Since 6d represents exclusively derivatives of 2-naphthol, its poor reactivity toward $o$-dichlorobenzene could be anticipated. However, 6d reacted more readily, than the parent 2-napthol to give isomeric 4-(3,4-dichlorophenyl)- and 4-(2,3-dichlorophenyl)-7-hydroxy2-tetralones 14 and $\mathbf{1 5}(9: 1)$ in 56\% overall yield (Chart 4).

Table 2. Condensation of Naphthalenediols $\mathbf{6 a}-\mathbf{c}$ with $o$-Dichlorobenzene

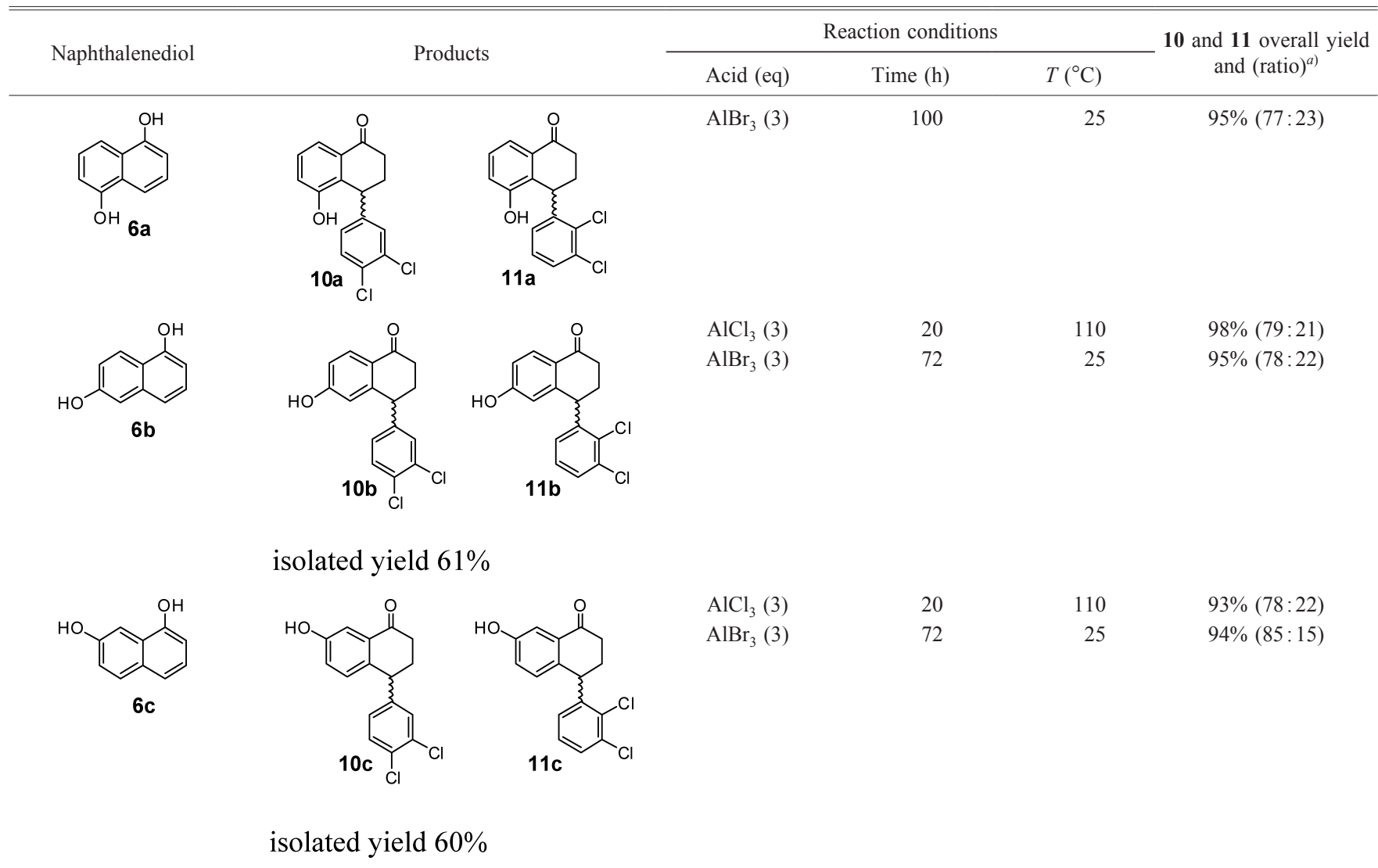


<smiles>[Y]c1cccc2c1CCCC2[Te]</smiles>

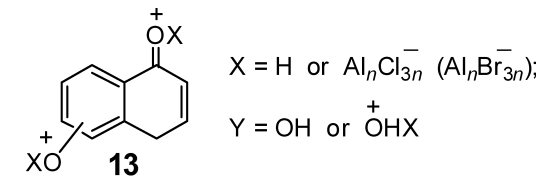

Notably, the reaction proceeded slowly, for $7 \mathrm{~d}$, in the presence of a 4-fold molar excess of $\mathrm{AlBr}_{3}$ at room temperature, whereas attempts to replace $\mathrm{AlBr}_{3}$ by $\mathrm{AlCl}_{3}$ were not successful. This is probably due to the lack of solubility of complexes of $\mathbf{6 d}$ with $\mathrm{AlCl}_{3}$ in $o$-dichlorobenzene at room temperature. Increasing the reaction time from one to two weeks did not change either the yield or the ratio of $\mathbf{1 4}$ and $\mathbf{1 5}$, which indicates the achievement of equilibrium values influencing both of these parameters.

A higher reactivity of $\mathbf{6 d}$ compared to that of 2-naphthol can be explained by invoking the intermediacy of tricationic species $\mathbf{1 6}$ (Chart 5), which is more electrophilic than dications 4. The intermediate $O, C$-diprotonated forms $17(\mathrm{X}=\mathrm{H})$ and similar complexes $17\left(\mathrm{X}=\mathrm{Al}_{n} \mathrm{Br}_{3 n}^{-}\right)$have been generated earlier as long-lived species in $\mathrm{HF}-\mathrm{SbF}_{5}-\mathrm{SO}_{2} \mathrm{ClF}$ and $\mathrm{AlBr}_{3}-\mathrm{CH}_{2} \mathrm{Br}_{2}$ superacid systems. ${ }^{43,44)}$ Alternatively, dicationic species 18, which is effectively stabilized by positive charge delocalization over an intact hydroxyl group, may also contribute to the reaction. Owing to a higher concentration of $\mathbf{1 8}$ (compared to 16), the equilibrium of reaction with $o$-dichlorobenzene could be shifted to tetralones $\mathbf{1 4}$ and $\mathbf{1 5}$ in spite of the diminished electrophilicity of $\mathbf{1 8}$.

From a synthetic point of view, the studied reactions of $\mathbf{6 d}$ and 2-naphthol may represent a convenient way to access dichlorophenyl-2-tetralones. The close derivative of product $\mathbf{1 4}$, 4-(3,4-dichlorophenyl)-7-methoxy-2-tetralone, as well as the parent product 7 are regarded as important intermediates in medicinal chemistry. ${ }^{8,34}$ These materials were produced previously by using inefficient multistep procedures. Therefore, the results obtained on the reactivity of 2-naphthols may be of practical interest. We suggest also that analogous reactions can be followed to obtain 2-tetralones with other deactivated (halogenated) aromatic compounds.

\section{Conclusions}

In summary, we have found that 2-naphthol and naphthalenediol 6d are able to react with $o$-dichlorobenzene under the influence of aluminum halides, which provide a new one-step procedure for the preparation of dichlorophenyl2-tetralones. Naphthalenediols $\mathbf{6 a}-\mathbf{c}$ condense with $o$-dichlorobenzene to give as the main products hydroxy substituted 4-(3,4-dichlorophenyl)-1-tetralones 10a-c. Since the starting materials are commercially readily available the reactions offer a convenient one step synthetic approach for preparation of novel derivatives of $\mathbf{2}$.

\section{Experimental}

General Remarks The ${ }^{1} \mathrm{H}$ - and ${ }^{13} \mathrm{C}-\mathrm{NMR}$ spectra were recorded on a Varian $300(300,75 \mathrm{MHz})$ or Bruker Avance III $500(500,125 \mathrm{MHz})$ NMR spectrometers. GC-MS spectra recorded on Agilent 5973N electron ionization/positive chemical ionization instrument. High-resolution mass spectra were measured at the Southern California Mass Spectrometry Facility at the University of California at Riverside. Aluminum

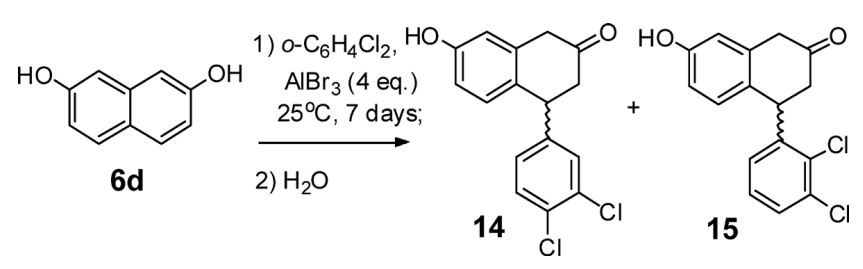

Chart 4. Condensation of Naphthalenediol 6d with $o$-Dichlorobenzene

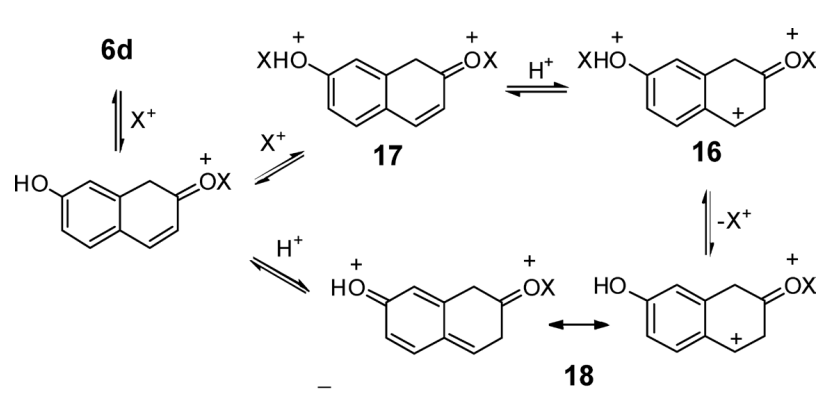

Chart 5. Superelectrophilic Activation of Naphthalenediol 6d Proposed

bromide, aluminum chloride, o-dichlorobenzene, 2-naphthol and naphthalendiols $\mathbf{6 a}-\mathbf{d}$ were purchased from suppliers and used as received.

4-(3,4-Dichlorophenyl)-2-tetralone (7) and 4-(2,3-Dichlorophenyl)-2-tetralone (8) To a stirred suspension of $\mathrm{AlCl}_{3}$ (freshly sublimed, $8.0 \mathrm{~g}, 60 \mathrm{mmol}$ ) in $o$-dichlorobenzene $(15 \mathrm{~mL})$ was added 2-naphthol $(2.9 \mathrm{~g}, 20 \mathrm{mmol})$. The mixture was saturated with gaseous $\mathrm{HCl}$ at $25^{\circ} \mathrm{C}$ for $20 \mathrm{~min}$. The resulting suspension was stirred at $25^{\circ} \mathrm{C}$ for 2 weeks, and then poured onto ice. The resulting mixture was extracted with ether. The organic phase was washed with dilute $\mathrm{HCl}$ and then several times with water. The organic solution was subjected to steam distillation to remove solvents and the rest of 2-naphthol. The residue was dissolved in ether, dried over anhydrous $\mathrm{MgSO}_{4}$ and concentrated in vacuo to give a brown, viscous oil [2.11 g (36\%), mixture of $\mathbf{7 / 8}(89: 11)$, according to ${ }^{1} \mathrm{H}-$ NMR spectroscopic data]. Compound 7: ${ }^{1} \mathrm{H}-\mathrm{NMR}(500 \mathrm{MHz}$, $\left.\mathrm{CD}_{3} \mathrm{OD}\right) \delta: 2.78(1 \mathrm{H}, \mathrm{dd}, J=16.5,7 \mathrm{~Hz}), 2.85(1 \mathrm{H}, \mathrm{dd}, J=16$, $5.5 \mathrm{~Hz}), 3.5(1 \mathrm{H}, \mathrm{d}, J=20.5 \mathrm{~Hz}), 3.68(1 \mathrm{H}, \mathrm{d}, J=20.5 \mathrm{~Hz}), 4.46$ $(1 \mathrm{H}, \mathrm{dd}, J=6.5,6 \mathrm{~Hz}), 6.92(1 \mathrm{H}, \mathrm{d}, J=7.5 \mathrm{~Hz}), 6.99$ (ddd, $J=8$, 2, $0.5 \mathrm{~Hz}, 1 \mathrm{H}), 7.16-7.24(4 \mathrm{H}, \mathrm{m}), 7.4(1 \mathrm{H}, \mathrm{d}, J=8 \mathrm{~Hz}) .{ }^{13} \mathrm{C}-$ NMR $\left(125 \mathrm{MHz}, \mathrm{CD}_{3} \mathrm{OD}\right) \delta: 45.1,45.3,46.6,127.1,127.2$, $128.2,128.7,129.9,130.4,131.2,131.9,133.6,136.4,139.3$, 144.3, 211.5. GC-MS $[\mathrm{M}]^{+}: 290$. The tetralone 7 is a known compound; spectroscopic data are listed here as an update. ${ }^{8)}$ Compound 8 (fragmentary data were taken from the spectrum of the mixture of products 7 and 8): ${ }^{1} \mathrm{H}-\mathrm{NMR}(500 \mathrm{MHz}$, $\left.\mathrm{CD}_{3} \mathrm{OD}\right) \delta: 2.81(1 \mathrm{H}, \mathrm{dd}, J=16.5,7 \mathrm{~Hz}), 2.87(1 \mathrm{H}, \mathrm{dd}, J=16$, $5.5 \mathrm{~Hz}), 3.62(1 \mathrm{H}, \mathrm{d}, J=20.5 \mathrm{~Hz}), 3.79(1 \mathrm{H}, \mathrm{d}, J=20.5 \mathrm{~Hz}), 5.0$ $(1 \mathrm{H}, \mathrm{t}, J=6.5 \mathrm{~Hz})$. GC-MS [M] $]^{+}: 290$.

4-(3,4-Dichlorophenyl)-6-hydroxy-1-tetralone (10b) and 4-(2,3-Dichlorophenyl)-6-hydroxy-1-tetralone (11b). Method a To a stirred suspension of $\mathrm{AlCl}_{3}(4.2 \mathrm{~g}, 37.5 \mathrm{mmol})$ in $o$-dichlorobenzene $(6 \mathrm{~mL})$ was added naphthalendiol $\mathbf{6 b}(2 \mathrm{~g}$, $12.5 \mathrm{mmol})$. The resulting mixture was stirred at $110^{\circ} \mathrm{C}$ for $20 \mathrm{~h}$, then cooled and poured over several grams of ice. After stirring the quenched mixture for $10 \mathrm{~min}$, hexane $(20 \mathrm{~mL})$ was added and stirring continued for $1 \mathrm{~h}$. The crude reaction product was filtered off, washed with water and hexane and 
dried to give $3.75 \mathrm{~g}(98 \%)$ of $\mathbf{1 0 b}$ and $\mathbf{1 1 b}$ mixture (the ratio $79: 21$, respectively, according to ${ }^{1} \mathrm{H}-\mathrm{NMR}$ spectroscopic data). Recrystallization of the mixture from aqueous ethanol (twice) and toluene (twice) gave tetralone $\mathbf{1 0 b}(2.33 \mathrm{~g}, 61 \%)$ as white crystals. Compound 10b: mp $240-241^{\circ} \mathrm{C}$. IR $\left(\mathrm{CHCl}_{3}\right)$ : $v=1655 \mathrm{~cm}^{-1}$. ${ }^{1} \mathrm{H}-\mathrm{NMR}\left(300 \mathrm{MHz}\right.$, acetone- $\left.d_{6}\right) \delta: 2.22-2.46$ (2H, m), 2.51-2.59 (2H, m), $4.36(1 \mathrm{H}, \mathrm{dd}, J=8.54,4.63 \mathrm{~Hz})$, $6.34(1 \mathrm{H}, \mathrm{d}, J=2.44 \mathrm{~Hz}), 6.86(1 \mathrm{H}, \mathrm{dd}, J=8.55,2.44 \mathrm{~Hz}), 7.2$ $(1 \mathrm{H}, \mathrm{dd}, J=8.3,2.2 \mathrm{~Hz}), 7.45(1 \mathrm{H}, \mathrm{d}, J=2.2 \mathrm{~Hz}), 7.57(1 \mathrm{H}, \mathrm{d}$, $J=8.3 \mathrm{~Hz}), 7.94(1 \mathrm{H}, \mathrm{d}, J=8.55 \mathrm{~Hz}), 9.13(\mathrm{~s}, 1 \mathrm{H}) .{ }^{13} \mathrm{C}-\mathrm{NMR}$ $\left(75 \mathrm{MHz}\right.$, acetone- $\left.d_{6}\right) \delta: 32.1,37.0,45.2,115.5,115.6,126.4$, $129.5,130.3,130.7,131.4,131.5,132.6,146.1,148.8,162.7$, 195.4. High resolution (HR)-MS Calcd for $\mathrm{C}_{16} \mathrm{H}_{12} \mathrm{Cl}_{2} \mathrm{O}_{2}[\mathrm{M}]^{+}$: 306.0214; Found 306.0225. Compound 11b (data were taken from the spectrum of the mixture of products $\mathbf{1 0 b}$ and 11b): ${ }^{1} \mathrm{H}-\mathrm{NMR}\left(300 \mathrm{MHz}\right.$, acetone- $\left.d_{6}\right) \quad \delta: 2.2-2.65$ (4H, m), 4.85 $(1 \mathrm{H}, \mathrm{t}, J=8 \mathrm{~Hz}), 6.34(1 \mathrm{H}, \mathrm{d}, J=2.2 \mathrm{~Hz}), 6.88(1 \mathrm{H}, \mathrm{dd}, J=8.2$, $2.2 \mathrm{~Hz}), 7.05(1 \mathrm{H}, \mathrm{dd}, J=8,1.6 \mathrm{~Hz}), 7.32(1 \mathrm{H}, \mathrm{t}, J=8 \mathrm{~Hz}), 7.54$ $(1 \mathrm{H}, \mathrm{dd}, J=8,1.6 \mathrm{~Hz}), 7.95(1 \mathrm{H}, \mathrm{d}, J=8.2 \mathrm{~Hz}), 9.16(1 \mathrm{H}, \mathrm{s})$.

Method b To a solution of $\mathrm{AlBr}_{3}(10 \mathrm{~g}, 37.5 \mathrm{mmol})$ in $o$ dichlorobenzene $(7 \mathrm{~mL})$ was added $\mathbf{6 b}(2 \mathrm{~g}, 12.5 \mathrm{mmol})$. The resulting mixture was stirred at $25^{\circ} \mathrm{C}$ for $72 \mathrm{~h}$, followed by the workup, as described above, to give $3.63 \mathrm{~g}(95 \%)$ of $\mathbf{1 0 b}$ and 11b $(78: 22)$ mixture.

4-(3,4-Dichlorophenyl)-7-hydroxy-1-tetralone (10c) and 4-(2,3-Dichlorophenyl)-7-hydroxy-1-tetralone (11c) Using the $\mathbf{a}$ and $\mathbf{b}$ methods, the mixtures of title compounds, $\mathbf{1 0} \mathbf{c}$ and 11c (the ratios $78: 22$ and $85: 15$, respectively) were prepared in 93-94\% yields. Recrystallization of the mixtures from toluene (twice) and ethanol (twice) gave 10c $(60 \%)$ as a white crystalline product. Compound 10c: mp $192-193^{\circ} \mathrm{C}$. IR $\left(\mathrm{CHCl}_{3}\right): v=1664 \mathrm{~cm}^{-1}$. ${ }^{1} \mathrm{H}-\mathrm{NMR}\left(300 \mathrm{MHz}\right.$, acetone- $\left.d_{6}\right)$ $\delta: 2.2-2.5(2 \mathrm{H}, \mathrm{m}), 2.55-2.65(2 \mathrm{H}, \mathrm{m}), 4.37(1 \mathrm{H}, \mathrm{dd}, J=8.06$, $3.42 \mathrm{~Hz}), 6.85(1 \mathrm{H}, \mathrm{d}, J=8.54 \mathrm{~Hz}), 7.02(1 \mathrm{H}, \mathrm{dd}, J=8.54$, $2.93 \mathrm{~Hz}), 7.16(1 \mathrm{H}, \mathrm{dd}, J=8.3,2.2 \mathrm{~Hz}), 7.41(1 \mathrm{H}, \mathrm{d}, J=2.2 \mathrm{~Hz})$, $7.47(1 \mathrm{H}, \mathrm{d}, J=2.93 \mathrm{~Hz}), 7.54(1 \mathrm{H}, \mathrm{d}, J=8.3 \mathrm{~Hz}), 8.68(\mathrm{~s}, 1 \mathrm{H})$. ${ }^{13} \mathrm{C}-\mathrm{NMR}\left(75 \mathrm{MHz}\right.$, acetone- $\left.d_{6}\right) \delta: 32.3,36.9,44.2,112.6$, $122.0,129.4,130.6,131.3,131.4,131.5,132.5,134.6,137.2$, 146.6, 157.2, 196.9. HR-MS Calcd for $\mathrm{C}_{16} \mathrm{H}_{12} \mathrm{Cl}_{2} \mathrm{O}_{2}[\mathrm{M}]^{+}$: 306.0214; Found 306.0214. Compound 11c (data were taken from the spectrum of the mixture of products $10 \mathrm{c}$ and 11c): ${ }^{1} \mathrm{H}-\mathrm{NMR}\left(300 \mathrm{MHz}\right.$, acetone- $\left.d_{6}\right) \quad \delta: 2.2-2.65(4 \mathrm{H}, \mathrm{m}), 4.85$ $(1 \mathrm{H}, \mathrm{dd}, J=6.84,1.95 \mathrm{~Hz}), 6.85(1 \mathrm{H}, \mathrm{d}, J=8.3 \mathrm{~Hz}), 6.92(1 \mathrm{H}$, $\mathrm{dd}, J=7.82,1.47 \mathrm{~Hz}), 7.04(1 \mathrm{H}, \mathrm{dd}, J=8.3,2.9 \mathrm{~Hz}), 7.28(1 \mathrm{H}$, t, $J=7.82 \mathrm{~Hz}), 7.49(1 \mathrm{H}, \mathrm{d}, J=2.9 \mathrm{~Hz}), 7.55(1 \mathrm{H}, \mathrm{dd}, J=7.82$, $1.47 \mathrm{~Hz}), 8.77(1 \mathrm{H}, \mathrm{s})$.

4-(3,4-Dichlorophenyl)-5-hydroxy-1-tetralone (10a) and 4-(2,3-Dichlorophenyl)-5-hydroxy-1-tetralone (11a) Using the $\mathbf{b}$ method (completion of the reaction required $100 \mathrm{~h}$ ), the mixture of title compounds, 10a and 11a (77:23) was prepared in $95 \%$ yield. HR-MS Calcd for $\mathrm{C}_{16} \mathrm{H}_{12} \mathrm{Cl}_{2} \mathrm{O}_{2}[\mathrm{M}]^{+}$: 306.0214; Found 306.0213. Compound 10a: ${ }^{1} \mathrm{H}-\mathrm{NMR}(300 \mathrm{MHz}$, acetone- $\left.d_{6}\right) \delta: 2.2-2.6(4 \mathrm{H}, \mathrm{m}), 4.71(1 \mathrm{H}, \mathrm{dd}, J=4.8,2 \mathrm{~Hz}), 7.06$ $(1 \mathrm{H}, \mathrm{dd}, J=8.3,2.2 \mathrm{~Hz}), 7.14(1 \mathrm{H}, \mathrm{dd}, J=7.81,1.2 \mathrm{~Hz}), 7.3(1 \mathrm{H}$, d, $J=2.2 \mathrm{~Hz}), 7.32(1 \mathrm{H}, \mathrm{t}, J=7.81 \mathrm{~Hz}), 7.48(1 \mathrm{H}, \mathrm{d}, J=8.3 \mathrm{~Hz})$, $7.59(1 \mathrm{H}, \mathrm{dd}, J=7.81,1 \mathrm{~Hz}), 8.77(1 \mathrm{H}, \mathrm{s}) .{ }^{13} \mathrm{C}-\mathrm{NMR}(75 \mathrm{MHz}$, acetone- $\left.d_{6}\right) \delta: 30.7,33.9,37.5,118.5,120.6,128.8,128.8,130.1$, 130.7, 130.9, 131.7, 132.3, 134.9, 145.1, 155.4, 197.1. Compound 11a: ${ }^{1} \mathrm{H}-\mathrm{NMR}\left(300 \mathrm{MHz}\right.$, acetone- $\left.d_{6}\right) \delta$ : 2.2-2.6 (4H, m), 5.09 $(1 \mathrm{H}, \mathrm{t}, J=8 \mathrm{~Hz}), 6.69(1 \mathrm{H}, \mathrm{dd}, J=7.8,1.4 \mathrm{~Hz}), 7.13(1 \mathrm{H}, \mathrm{dd}$, $J=7.8,1.2 \mathrm{~Hz}), 7.17(1 \mathrm{H}, \mathrm{t}, J=7.8 \mathrm{~Hz}), 7.33(1 \mathrm{H}, \mathrm{t}, J=7.8 \mathrm{~Hz})$,
$7.47(1 \mathrm{H}, \mathrm{dd}, J=7.8,1.4 \mathrm{~Hz}), 7.61(1 \mathrm{H}, \mathrm{dd}, J=7.8,1.2 \mathrm{~Hz}), 8.77$ $(1 \mathrm{H}, \mathrm{s})$.

4-(3,4-Dichlorophenyl)-7-hydroxy-2-tetralone (14) and 4-(2,3-Dichlorophenyl)-7-hydroxy-2-tetralone (15) То а solution of $\mathrm{AlBr}_{3}(28.4 \mathrm{~g}, 0.105 \mathrm{~mol})$ in $o$-dichlorobenzene $(30 \mathrm{~mL})$ was added $\mathbf{6 d}(4.2 \mathrm{~g}, 0.026 \mathrm{~mol})$. The resulting solution was stirred at $25^{\circ} \mathrm{C}$ for 1 week, and then poured onto ice. The resulting mixture was extracted with ether. The organic phase was washed with dilute $\mathrm{HCl}$ and then several times with water. The organic solution was subjected to steam distillation to remove solvents and the rest of $\mathbf{6 d}$ (which is soluble in a hot water). After removing of a hot water solution and cooling the residue, a brown solid was isolated to give a mixture of title compounds, 14 and $\mathbf{1 5}(89: 11)$ in $56 \%$ overall yield. Recrystallization of the mixture from hexane gave $2.99 \mathrm{~g}(37 \%)$ of 14 as a pale-yellow crystalline product. Compound 14: $\mathrm{mp}$ 93-95 ${ }^{\circ}$. ${ }^{1} \mathrm{H}-\mathrm{NMR}\left(500 \mathrm{MHz}, \mathrm{CD}_{3} \mathrm{OD}\right) \delta: 2.8(1 \mathrm{H}, \mathrm{dd}, J=16.5$, $7 \mathrm{~Hz}), 2.89(1 \mathrm{H}, \mathrm{dd}, J=16,5.5 \mathrm{~Hz}), 3.45(1 \mathrm{H}, \mathrm{d}, J=20.5 \mathrm{~Hz})$, $3.64(1 \mathrm{H}, \mathrm{d}, J=20.5 \mathrm{~Hz}), 4.43(1 \mathrm{H}, \mathrm{t}, J=6 \mathrm{~Hz}), 6.63-6.68(2 \mathrm{H}$, m), $6.79(1 \mathrm{H}, \mathrm{d}, J=8 \mathrm{~Hz}), 7.02(1 \mathrm{H}, \mathrm{dd}, J=8.5,2.5 \mathrm{~Hz}), 7.24$ $(1 \mathrm{H}, \mathrm{d}, J=2 \mathrm{~Hz}), 7.42(1 \mathrm{H}, \mathrm{d}, J=8.5 \mathrm{~Hz}) .{ }^{13} \mathrm{C}-\mathrm{NMR}(125 \mathrm{MHz}$, $\left.\mathrm{CD}_{3} \mathrm{OD}\right) \delta: 43.6,44.6,45.2,115.2,116.2,128.9,130.0,130.2$, 131.1, 131.6, 131.8, 133.5, 136.1, 145.2, 157.9, 211.7. HR-MS Calcd for $\mathrm{C}_{16} \mathrm{H}_{12} \mathrm{Cl}_{2} \mathrm{O}_{2}[\mathrm{M}]^{+}$: 306.0214; Found 306.0210. Compound 15 (fragmentary data were taken from the spectrum of the mixture of products $\mathbf{1 4}$ and $\mathbf{1 5})$ : ${ }^{1} \mathrm{H}-\mathrm{NMR}(500 \mathrm{MHz}$, $\left.\mathrm{CD}_{3} \mathrm{OD}\right): \delta: 2.76(1 \mathrm{H}, \mathrm{dd}, J=16.5,7 \mathrm{~Hz}), 2.87(1 \mathrm{H}, \mathrm{dd}, J=16$, $5.5 \mathrm{~Hz}), 3.54(1 \mathrm{H}, \mathrm{d}, J=20.5 \mathrm{~Hz}), 3.7(1 \mathrm{H}, \mathrm{d}, J=20.5 \mathrm{~Hz}), 4.92$ $(1 \mathrm{H}, \mathrm{dd}, J=6.5,6 \mathrm{~Hz})$. GC-MS $[\mathrm{M}]^{+}: 306$.

Acknowledgments Financial support of the work by the National Science Foundation and the Loker Hydrocarbon Research Institute is gratefully acknowledged.

\section{References and Notes}

1) Williams M., Quallich G., Chem. Ind., 10, 315-319 (1990).

2) Meyer M. D., Hancock A. A., Tietje K., Sippy K. B., Prasad R., Stout D. M., Arendsen D. L., Donner B. G., Carroll W. A., J. Med. Chem., 40, 1049-1062 (1997).

3) Vukics K., Fodor T., Fischer J., Fellegvary I., Levai S., Org. Process Res. Dev., 6, 82-85 (2002).

4) Descamps-François C., Yous S., Chavatte P., Audinot V., Bonnaud A., Boutin J. A., Delagrange P., Bennejean C., Renard P., Lesieur D., J. Med. Chem., 46, 1127-1129 (2003).

5) Kim H., Kim K., Chung Y. K., J. Org. Chem., 71, 8264-8267 (2006).

6) Souvie J.-C., Blanco I. G., Thominot G., Chapuis G., Horvath S., Damien G., U.S. Patent 7250531 (2007).

7) Lucarini S., Bedini A., Spadoni G., Piersanti G., Org. Biomol. Chem., 6, 147-150 (2008).

8) Shao L., Wang F., Malcolm S. C., Ma J., Hewitt M. C., Campbell U. C., Bush L. R., Spicer N. A., Engel S. R., Saraswat L. D., Hardy L. W., Koch P., Schreiber R., Spear K. L., Varney M. A., Bioorg. Med. Chem., 19, 663-676 (2011).

9) Welch W. M., Kraska A. R., Sarges R., Koe B. K., J. Med. Chem., 27, 1508-1515 (1984)

10) Koe B. K., Weissman A., Welch W. M., Browne R. G., J. Pharmacol. Exp. Ther., 226, 686-700 (1983).

11) Corey E. J., Gant T. G., Tetrahedron Lett., 35, 5373-5376 (1994).

12) Quallich G. J., Woodall T. M., Tetrahedron, 48, 10239-10248 (1992).

13) Lautens M., Rovis T., J. Org. Chem., 62, 5246-5247 (1997).

14) Chen C.-Y., Reamer R. A., Org. Lett., 1, 293-294 (1999). 
15) Quallich G. J., Williams M. T., Friedmann R. C., J. Org. Chem., 55, 4971-4973 (1990).

16) Guy A., Eur. Patent 346226 (1989).

17) Repinskaya I. B., Koltunov K. Yu., Sib. Khim. Zh., 3, 73-76 (1993).

18) "Methoden der Organischen Chemie," Vol. 7, 2b, ed. by Thomas H. G., Thieme, Stuttgart, 1976, p. 1710.

19) Koptyug V. A., Andreeva T. P., J. Org. Chem. USSR, 7, 2490-2495 (1971).

20) Repinskaya I. B., Koryabkina N. A., Makarova Z. S., Koptyug V. A., J. Org. Chem. USSR, 18, 754-760 (1982).

21) Repinskaya I. B., Barkhutova D. D., Makarova Z. S., Alekseeva A. V., Koptyug V. A., J. Org. Chem. USSR, 21, 759-767 (1985).

22) Repinskaya I. B., Koltunov K. Yu., Shakirov M. M., Shchegoleva L. N., Koptyug V. A., Russ. J. Org. Chem., 29, 803-810 (1993).

23) Koltunov K. Yu., Repinskaya I. B., Shakirov M. M., Shchegoleva L. N., Koptyug V. A., Russ. J. Org. Chem., 30, 88-96 (1994).

24) Koltunov K. Yu., Subbotina E. N., Repinskaya I. B., Russ. J. Org. Chem., 33, 689-693 (1997).

25) Koltunov K. Yu., Ostashevskaya L. A., Repinskaya I. B., Russ. J. Org. Chem., 34, 1796-1797 (1998).

26) Olah G. A., Klumpp D. A., "Superelectrophiles and Their Chemistry," Wiley, New York, 2008.

27) Repinskaya I. B., Shakirov M. M., Koltunov K. Yu., Koptyug V. A., J. Org. Chem. USSR, 24, 1719-1727 (1988).

28) Repinskaya I. B., Koltunov K. Yu., Shakirov M. M., Koptyug V. A., J. Org. Chem. USSR, 28, 785-793 (1992).

29) Ostashevskaya L. A., Koltunov K. Yu., Repinskaya I. B., Russ. J. Org. Chem., 36, 1474-1477 (2000).

30) Koltunov K. Yu., Sobolev V. I., RU Patent 2356883 (2009).

31) Koltunov K. Yu., Tetrahedron Lett., 49, 3891-3894 (2008).

32) Koltunov K. Yu., Prakash G. K. S., Rasul G., Olah G. A., Tetrahedron, 58, 5423-5426 (2002).
33) Reactions of isomeric 1,3- and 1,4-naphthalenediols with $o$-dichlorobenzene were not studied taking into account their poor reactivity towards comparatively stronger nucleophiles, such as benzene and cyclohexane (see, please, refs. 22-24), whereas the reactivity of 2,6-naphthalenediol was expected to be similar to that of $\mathbf{6 d}$ in analogy to reaction with benzene (ref. 31).

34) Shao L., Wang F., Malcolm S. C., Hewitt M. C., Bush L. R., Varney M. A., Campbell U. C., Engel S. R., Hardy L. W., Koch P., Ma J., Patent W.O., 2007/081542 (2007).

35) Koltunov K. Yu., Prakash G. K. S., Rasul G., Olah G. A., J. Org. Chem., 67, 4330-4336 (2002).

36) Koptyug V. A., Andreeva T. P., Mamatyuk V. I., J. Org. Chem. USSR, 6, 1859-1864 (1970).

37) Olah G. A., Prakash G. K. S., Sommer J., Molnar A., "Superacid Chemistry," 2nd ed., Wiley, 2009.

38) Smith G. P., Dworkin A. S., Pagni R. M., Zingg S. P., J. Am. Chem. Soc., 111, 525-530 (1989).

39) Smith G. P., Dworkin A. S., Pagni R. M., Zingg S. P., J. Am. Chem. Soc., 111, 5075-5077 (1989).

40) Koltunov K. Yu., Prakash G. K. S., Rasul G., Olah G. A., J. Org. Chem., 72, 7394-7397 (2007).

41) Koltunov K. Yu., Walspurger S., Sommer J., Chem. Commun. (Camb.), 15, 1754-1755 (2004).

42) Koltunov K. Yu., Prakash G. K. S., Rasul G., Olah G. A., Heterocycles, 62, 757-772 (2004).

43) Kamshii L. P., Author's Abstract of Thesis for Candidate of Chemical Sciences, Novosibirsk, 1976.

44) Kamshii L. P., Mamatyuk V. I., Koptyug V. A., Zh. Org. Khim., 10, 2194-2199 (1974).

45) Welch W. M. Jr., Harbert C. A., Koe B. K., Kraska A. R., U.S. Patent 4556676 (1985). 